\title{
DOROTA MAŚNIAK
}

https://doi.org/10.33995/wu2020.2.7

\section{Bartosz Kucharski}

\section{Świadczenie ubezpieczyciela w umowie ubezpieczenia mienia}

\section{WYDAWNICTWO WOLTERS KLUWER, WARSZAWA-ŁÓDŹ 2019, 605 STRON}

Monografia Bartosza Kucharskiego stanowi całościowe opracowanie zagadnienia świadczenia ubezpieczyciela mienia, potraktowanego jako punkt odniesienia dla ekspansywnie rozwijających się ubezpieczeń majątkowych. Ta kluczowa dla nauki prawa ubezpieczeniowego problematyka nie doczekała się dotychczas kompleksowego opracowania. Autor podjał w pełni udaną próbę zdiagnozowania i wyjaśnienia najistotniejszych problemów dotyczących umowy ubezpieczenia mienia. Funkcjonalny charakter ma szerokie ujęcie ubezpieczeń mienia, przez które Autor rozumie ubezpieczenia majątkowe niebędące ubezpieczeniami odpowiedzialności cywilnej. Tak szerokie ujęcie ubezpieczeń mienia implikuje włączenie w zakres badań ubezpieczeń majątkowych o bardzo niejednorodnym charakterze. Ów zbiór obejmuje zarówno najpopularniejsze ubezpieczenia od ognia i innych zdarzeń losowych czy też ubezpieczenia autocasco, którym Autor poświęca sporo miejsca, jak i ubezpieczenia ryzyk finansowych czy kosztów. Poszukiwanie zasad rządzących takim zbiorem jest zadaniem niełatwym i zasługuje na uznanie.

Tym samym monografia wypełnia lukę w piśmiennictwie, prezentując bardzo wysoki poziom merytoryczny. Wybór i sposób ujęcia badanych zagadnień - stanowiących „rdzeń” prywatnoprawnego prawa ubezpieczeniowego - dowodzą, że Bartosz Kucharski jest wytrawnym znawca i badaczem nie tylko prawa ubezpieczeniowego, ale (jeśli nie przede wszystkim) prawa cywilnego. Temat pracy nie pojawił się ad hoc, ale jest wyrazem długotrwałej i rzetelnej pracy badawczej. Uwadze Autora nie uszło żadne z istotnych zagadnień. Kolejne strony książki utwierdzają czytelnika w przekonaniu, że ma do czynienia ze znawcą i ekspertem w badanej dziedzinie.

Analizując poszczególne kwestie, Autor przed wyprowadzeniem własnych wniosków dokładnie relacjonuje występujące w nauce poglądy, uwypukla ich wady i zalety. Takie podejście świadczy tak o dużej erudycji Autora, jak i o jego uczciwości i rzetelności badawczej. Liczne wạtki 
prawnoporównawcze są dowodem dużej wnikliwości badacza. Dobry przykład stanowi wykorzystanie sporu toczącego się w prawie angielskim dotyczącego kwestii ubiegania się odszkodowania z tytułu nienależytego wykonania umowy ubezpieczenia, w szczególności za zwłokę.

Pierwszy rozdział pracy ma charakter teoretyczny. Autor mierzy się w nim z kluczowym dla prawa pytaniem o odpowiedzialność. Weryfikuje tezę o uznaniu sytuacji ubezpieczyciela za odpowiedzialność i dalej o odszkodowawczym charakterze tej odpowiedzialności. Konfrontuje się przy tym z pogladami głoszonymi przez autorytety prawa zobowiązań i prawa ubezpieczeniowego. Już w pierwszym rozdziale widoczna jest charakteryzująca cała pracę wnikliwość i precyzja terminologiczna. Za szczególnie cenne uznaję usytuowanie odpowiedzialności ubezpieczeniowej w obrębie typów, reżimów i zasad odpowiedzialności i konsekwentne analizowanie badanej problematyki w oparciu o przyjęta klasyfikację. W dobie chaosu terminologicznego, dotykajacego w szczególności dziedziny prawa poddawane harmonizacji przez prawo unijne, takie podejście uznać należy za wzorcowe.

Drugi rozdział został poświęcony zagadnieniu treści świadczenia ubezpieczyciela, w szczególności sporu pomiędzy zwolennikami teorii świadczenia pieniężnego i teorii ponoszenia ryzyka. Autor jest zwolennikiem tzw. zmodyfikowanej teorii ryzyka, godzaccej obie wyżej wymienione. Na szczególną uwagę zasługują rozważania dotyczące kwalifikacji zobowiązania z umowy ubezpieczenia przed zajściem wypadku ubezpieczeniowego jako zobowiązania naturalnego. Uznając umowę ubezpieczenia za umowę wzajemną, Autor tę cechę wiąże z losowością, a nie z przyjętą teorią. Kwestia ta od lat stanowi przedmiot rozważań polskiej doktryny prawa ubezpieczeniowego. Autor podjał próbę odpowiedzi na pytanie o znaczenie cechy wzajemności dla wykonywania umowy.

Kolejnym krokiem w dążeniu do sprecyzowania zakresu świadczenia odszkodowawczego było ustalenie i omówienie przesłanek odpowiedzialności ubezpieczeniowej ujmowanej jako obowiązek zapłaty odszkodowania w razie zajścia wypadku ubezpieczeniowego. Autor zalicza do nich: zawarcie umowy ubezpieczenia, zajście wypadku ubezpieczeniowego, szkodę ubezpieczeniowa i związek przyczynowy. W rozważaniach poświęconych pojęciu wypadku ubezpieczeniowego na uwagę zasługuje polemika Bartosza Kucharskiego z popularnym w doktrynie poglądem, zgodnie z którym skutek prawny wywołany przez zajście wypadku polegać ma na przekształceniu prawa do świadczenia ubezpieczeniowego w prawo istniejące. Autor wyeksponował wyniki analizy szkody w rozumieniu prawa ubezpieczeniowego (szkody ubezpieczeniowej), poszukując odpowiedzi na pytanie o różnicę w jej ujmowaniu w porównaniu do szkody na gruncie reguł ogólnych. Zgadzam się z podkreślaną w książce kluczową rolą teorii lokalizacji szkody dla ustalania granic szkody ubezpieczeniowej.

Czwarty rozdział monografii został poświęcony konstrukcjom prawa ubezpieczeniowego determinującym ograniczony co do zasady charakter odszkodowania ubezpieczeniowego. Również w tym rozdziale Autor wykazuje się umiejętnością precyzyjnego diagnozowania problemów nurtujacych doktrynę prawnoubezpieczeniowa, jak choćby sporu o to, czy w przypadku ubezpieczenia w wartości nowej i otaksowanej dochodzi do przełamania zasady odszkodowania. Poszukując rozstrzygnięcia, Autor porządkuje klasyfikację wartości ubezpieczenia. Sporo miejsca poświęca wartości otaksowanej budzącej najwięcej kontrowersji w doktrynie. Słusznie wskazuje na ryzyko związane ze stosowaniem w praktyce takiej wartości w oderwaniu od zasady odszkodowania prowadzące do zbliżenia umowy ubezpieczenia do umowy hazardowej. Rozważania dotyczące ustalania wartości ubezpieczonych pojazdów na podstawie systemów i programów dowodzą umiejętności wykorzystania dużej wiedzy praktycznej i rozwiązań prawnych obowiązujących w innych 
systemach prawnych (tu instytucji estopel) dla samodzielnego wyciagania precyzyjnych wniosków ( w tym de lege ferenda). Autor ostrożnie wypowiada się na temat zakresu dopuszczalności stosowania klauzuli proporcjonalności. Stawia zarzut, iż stosowanie klauzuli proporcji traktowane jest jako wybieg mający pozwolić przynajmniej na zaniżenie wartości odszkodowania w sytuacjach, gdy nie będzie można całkowicie uniknąć odpowiedzialności. Na uwagę zasługuje natomiast propozycja Autora dotycząca przekształcenia klauzuli proporcji w wersji niedozwolonej w klauzulę w wersji dozwolonej. Jest to dobrze uzasadniona propozycja rozwiązania problemu nękającego praktykę ubezpieczeniowa, czyni ona zbytecznym postulat ujawniania tej klauzuli w treści polisy. Element rozwojowy w prawie ubezpieczeniowym zawierają również rozważania dotyczące systemu rozliczeń między ubezpieczycielami w przypadku podwójnego ubezpieczenia, poddające analizie przyjęte w systemach prawnych koncepcje odpowiedzialności (maksymalnej i niezależnej).

W kolejnym rozdziale Bartosz Kucharski podejmuje próbę odpowiedzi na pytanie: czy i w jakim zakresie do odszkodowania ubezpieczeniowego stosuje się reguły natury ogólnej. Odnosząc się do kolejnych zagadnień związanych z odszkodowaniem ubezpieczeniowym, mierzy się Autor z kluczowym dla problematyki klauzul niedozwolonych zagadnieniem „głównego świadczenia stron umowy". Stoi na stanowisku, że ów termin należy odnieść do granic odszkodowania bezpośrednio powiązanych z wysokością składki. Tak wąska interpretacja prowadzi go do kontrowersyjnej tezy, że postanowienia OWU nieprzewidujące wypłaty odszkodowania odpowiadającego ubytkowi wartości handlowej pojazdu moga być w określonych sytuacjach uznane za klauzule niedozwolone, a nawet za wykraczające poza dopuszczalny zakres swobody umów. Trudno odmówić Autorowi konsekwencji w prowadzonej analizie. Na uwagę w tym rozdziale zasługują wywody poświęcone kosztom ratowania, traktowanym jako składnik odszkodowania. Za wkład do rozwoju prawa ubezpieczeniowego uznać należy rozważania poświęcone interpretacji art. 826 k.c. odnoszącego się do czasowego zakresu zwrotu kosztów. Autor z powodzeniem broni tezy, w myśl której ubezpieczajacy ma prawo do zwrotu kosztów akcji ratowniczej niezależnie od tego, czy doszło do wypadku, wiążąc ja ściśle ze sposobem określenia w umowie ubezpieczenia wypadku ubezpieczeniowego. Godny rozważenia jest również wniosek de lege ferenda uniezależniający wysokość celowych kosztów ratowania od wysokości sumy ubezpieczenia.

Szósty rozdział dotyczy wyłączeń odpowiedzialności ubezpieczyciela traktowanych przez Autora jako doprecyzowanie zakresu odpowiedzialności ubezpieczyciela. Istotny głos w dyskusji toczącej się w doktrynie prawa ubezpieczeniowego stanowią rozważania poświęcone interpretacji i zakresowi stosowania klauzuli reprezentantów. Na uwagę zasługuje interpretacja art. 827 § 3 k.c. jako odzwierciedlenie zgody ustawodawcy na dostosowanie przez strony brzmienia ww. klauzuli do rodzaju konkretnego ubezpieczenia. Poddając analizie klauzulę reprezentantów w kontekście odpowiedzialności za szkody spowodowane przez pracownika, Autor wiąże zakres owej klauzuli z możliwością kontroli przez ubezpieczającego oraz brakiem losowości działań lub zaniechań pracownika z punktu widzenia ubezpieczającego. Taka interpretacja stanowi cenną wytyczną w formułowaniu OWU w zakresie kształtowania klauzul wyłączających odpowiedzialność. Rozważania Autora stanowią ważną odpowiedź na pytanie o zakres umownej modyfikacji klauzuli reprezentantów. Poczesne miejsce zajmują rozważania dotyczące zagadnienia związku przyczynowego między naruszeniem powinności ubezpieczającego określonym w OWU a wypadkiem ubezpieczeniowym. Za cenny wkład do nauki prawa ubezpieczeniowego uważam propozycję reguł interpretacyjnych ułatwiających odróżnianie powinności prewencyjnych i klauzul wyłączających odpowiedzialność ubezpieczyciela, opartą na wnikliwej analizie reprezentatywnych systemów prawnych, zasad 
europejskiego prawa o umowie ubezpieczenia (PEICL) oraz orzecznictwa sądów powszechnych i SOKIK. Choć Bartosz Kucharski skromnie podkreśla, że jego rozważania nie wyjaśniaja wszelkich wątpliwości, to stanowczo stwierdzam, że mogą stanowić istotna pomoc w rozstrzyganiu problemu nękającego praktykę ubezpieczeniową. Kompromis pomiędzy zwolennikami teorii ponoszenia ryzyka i teorii świadczenia pieniężnego stanowić może zaproponowana przez Autora interpretacja pojęcia „głównego świadczenia” ubezpieczyciela w rozumieniu art. 385 §1 k.c., którym jest świadczenie spełniane w razie zajścia wypadku ubezpieczeniowego, a nie ochrona ubezpieczeniowa rozumiana jako świadczenie ubezpieczyciela w szerszym znaczeniu. Taka interpretacja wpływa na rozszerzenie granic kontroli wzorca, pozostawiając poza jej zakresem jedynie klauzule odnoszące się do samej istoty określenia w danej umowie wypadku ubezpieczeniowego oraz pozostajace w bezpośredniej relacji z wymiarem składki ubezpieczeniowej.

Ostatni rozdział stanowi wnikliwą analizę zagadnienia restytucji naturalnej, którego znaczenie istotnie wzrosło w związku z dynamicznym rozwojem rynku usług, w którym ubezpieczyciele jako podmioty rynku finansowego chętnie uczestniczą. Dostrzegany przez doktrynę dylemat dopuszczalności restytucji naturalnej jako sposobu naprawienia szkody zyskał nowy wymiar. Wypowiedzi Autora stanowią impuls do pogłębionej dyskusji, której dotąd brak było w polskiej doktrynie. Słusznie Autor zauważa, iż właśnie w działalności ubezpieczeniowej różnica między restytucją naturalną a zapłaceniem w pieniądzu odszkodowania mającego sfinansować koszty przywrócenia do stanu poprzedniego szczególnie się zaciera. Pogłębiona analiza kwestii dopuszczalności restytucji naturalnej prowadzi Autora do odpowiedzi na bardziej generalne i kluczowe dla rozwoju ubezpieczeń pytanie: jakie zdarzenia mogą być objęte różnymi postaciami ubezpieczeń, czyli - innymi słowy - co rozumiemy przez działalność ubezpieczeniową i jakie sa jej granice. Trudno nie zgodzić się z Bartoszem Kucharskim, że oderwanie ubezpieczenia od kwestii interesu, ryzyka, losowości i od zasady odszkodowania jest sprzeczne z właściwością, naturą kreowanego stosunku prawnego i jako takie wykracza poza dopuszczalny zakres zasady swobody umów.

Co stanowi rzadkość w tego rodzaju pracach, pomimo specjalistycznego charakteru rozważań i licznych odniesień rozprawę czyta się z lekkością i niesłabnącym zaciekawieniem. Jest to zasługa precyzyjnego języka, rzetelności badawczej i odwagi Autora, który konsekwentnie „rozbraja” kolejne przeszkody, nie uciekając się przy tym do ogólników czy zawiłych dyskursów, w których trudno doszukać się sedna. Jego wywód jest jasny i klarowny.

Jest to monografia, której walory umiejscawiaja ja wśród opracowań wytyczających kierunki rozwoju polskiej szkoły prawa ubezpieczeniowego. Nie waham się stwierdzić, że będą do niej sięgać kolejne pokolenia zaintersowane problematyką ubezpieczeniową.

DR HAB, PROF. UG DOROTA MAŚNIAK - kierownik Pracowni Prawa Ubezpieczeniowego w Katedrze Prawa Cywilnego, Uniwersytet Gdański

e-mail: d.masniak@prawo.univ.gda.pl

https://orcid.org/0000-0001-7521-422 